\title{
Idiopathic pulmonary fibrosis: the need for early diagnosis
}

\author{
${\text { Gaetano } \text { Cicchitto }^{1 *} \text { and Claudio M Sanguinetti }}^{2}$
}

\begin{abstract}
Idiopathic pulmonary fibrosis (IPF), a chronic fibrosing lung disease of a progressive nature and unknown etiology, has the largest epidemiological impact and the worst prognosis among the idiopathic interstitial pneumonias (IIP). Despite the progress in pathogenetic knowledge, many aspects are still dubious, in particular the biomolecular mechanisms activated in the early stages of the disease. Early diagnosis is desirable not only to better define aspects of the natural history of the disease, but also to customize treatment protocols. An early diagnosis of IPF should necessarily be based on the ability to highlight a number of features drawn not only from a careful composition of specific anamnestic data with clinical, functional and radiological parameters, but also from biological markers that, in a proper context, can provide guidance and confirm a clinical-anamnestic suspicion. The identification of specific biomarkers for IPF is a modern and attractive look for the potential clinical implications in terms of diagnosis, prediction of disease progression and prognosis. Biomolecular investigations on IPF were performed selectively on tissue samples, bronchoalveolar lavage (BAL), or blood: nowadays the "multi-omic" approach may allow studying individual constitutional profiles resorting to a series of biomolecular disciplines, the so-called "omics", which focuses on responses of the entire genomic complex, in line with the current trend to quantitatively analyze the interactions of all components of a biological system. Such refined investigations are an essential base for research now, but they might become a routine in the near future, allowing a more precise classification of patients suffering from a disease of unclear taxonomy.
\end{abstract}

Keywords: Biomarkers, Early diagnosis, Idiopathic pulmonary fibrosis, Omics

\section{Review}

Idiopathic pulmonary fibrosis (IPF) is a chronic fibrosing lung disease, of a progressive nature, unknown etiology, limited to the lung, which, in the context of the idiopathic interstitial pneumonias (IIP), has the largest epidemiological impact and the worst prognosis [1]. Epidemiological data still qualify IPF as a "rare disease", even if international studies seem to report an increasing incidence [2,3]. It is uncertain, however, whether this depends on the aging of the population, changes in smoking habits, environmental exposure to pneumotoxic substances, greater awareness and possibilities to make a diagnosis of the disease, or a combination of these factors [4].

Unlike other pulmonary diseases (Chronic Obstructive Lung Disease (COPD), neoplasms), neither risk factors nor natural history are clear for IPF. In addition, despite

\footnotetext{
* Correspondence: gaeint@libero.it

'RespiratoryPhysiopathology Unit, ASL SA, Cava de' Tirreni, SA, Italy

Full list of author information is available at the end of the article
}

the progress in pathogenetic knowledge, many aspects are still dubious; among these, in particular the biomolecular mechanisms activated in the early stages of the disease. The most significant consequence of such uncertainty is a delay in clinical suspicion, so that diagnosis is usually made when clinical objectivity and anathomoradiological alterations have already achieved an irreversible expression.

The growing incidence and an inexorable progression of IPF to functional impairment have not only directed research towards the understanding of the pathogenesis and molecular bases of the disease $[5,6]$, but also encouraged the academic community to propose a number of therapeutic trials [7], particularly in the last years. These trials, however, have not provided solid and unequivocal efficacy [8], with one possible exception for pirfenidone [9], on the real usefulness of which, however, a general agreement has not been reached yet [10]. The variability of the clinical course in each patient and the
C Biomed Central

(c) 2013 Cicchitto and Sanguinetti; licensee BioMed Central Ltd. This is an Open Access article distributed under the terms of the Creative Commons Attribution License (http://creativecommons.org/licenses/by/2.0), which permits unrestricted use, distribution, and reproduction in any medium, provided the original work is properly cited. 
difficulty to set up and properly assess clinical trials [11] explain, at least partially, the lack of consistency of the results of such trials and the non-uniformity of interpretation of the data one can find in literature. In this context, it is notable the unavailability of trials involving the initial stages of the disease, i.e. when the variable pathobiological processes in progress could be, at least in theory, reversible.

Early diagnosis is, therefore, desirable not only to better define some aspects of the natural history of the disease, but also to customize treatment protocols that at this time are inevitably limited to the above mentioned clinical trials. This in order to optimize the clinical management of patients, who are still faced with a particularly unfavorable prognosis in the short and medium term, as demonstrated by several survival studies [12].

However, the early diagnosis of IPF is not easy for a number of reasons. A first difficulty is the non-specificity of clinical symptoms at onset (non-productive cough, exertional dyspnea). It was observed that 1 to 3 years may elapse between the onset of symptoms and the specialist's assessment, while the delay in diagnosis can even increase up to 5 years [13]. Functional evaluations do not add to specificity of clinical suspicion: a restrictive ventilatory defect, and a reduction in lung volumes in particular, as well as an alteration of the diffusing capacity of the lung for carbon monoxide $\left(\mathrm{DL}_{\mathrm{CO}}\right)$, are a common feature of various interstitial lung diseases (ILD). In addition, lung volume can remain unaltered if there is a concomitant emphysema [14], an association that can be justified by smoking exposure, which represents a common risk factor for both disorders.

Regarding imaging aspects, high-resolution chest tomography (HRCT) is the method of choice to highlight a pattern of usual interstitial pneumonia (UIP), the pathological-radiological substrate of IPF, the detection of which may be based on the distinguishing feature of honeycombing [1]. Unfortunately, this aspect is difficult to grasp until some more overt alterations appear, such as the reticular pattern at the bases and in the periphery of the lung, the presence of micro-cysts, the scarcity of ground glass, aspects, etc. [15].

In the light of the foregoing issues, an early diagnosis of IPF should necessarily be based on the ability to highlight, in the very early phases of the disease, a number of features drawn not only from a careful composition of specific anamnestic data with clinical, functional and radiological parameters, but also from biological markers (biomarkers) that, in a proper context, can provide guidance and confirm a clinical-anamnestic suspicion.

In general, a biomarker indicates a measurable biological characteristic (e.g. the concentration of a protein in a biological fluid, a specific functional parameter, a particular morphological expression in HRCT, and so on) at a certain time in a given disease, correlated with the presence, the progression and/or therapeutic responsiveness of the disease [16].

The identification of specific biomarkers for IPF is a modern look and attractive for the potential clinical implications in terms of diagnosis, prediction of disease progression and prognosis. An ideal biomarker should be easily accessible, measurable and suitable to be used for longitudinal assessment [17]. The need of having such indicators available is related to several purposes. First, to overcome limitations arising from the current diagnostic criteria: radiological aspects are not only late, but also sometimes not univocal in interpretation. On the other hand, surgical biopsy is very often not feasible for both the poor "performance status" of patients and their refusal to undergo a surgical procedure. In any case, a special expertise is requested for radiological and surgical procedure and interpretation, only possible in reference centers. Secondly, the availability of biomarkers repeatable over time can improve the clinical management of the patients, making it possible, for example, to provide prognostic information and optimize the inclusion in the lists of lung transplantation.

The identification and mapping of the human genome have led to the introduction of increasingly sophisticated analytical methods and the emergence of new molecular disciplines (genomics, transcriptomics, proteomics, metabolomics: omics). Accordingly, a re-profiling of various respiratory diseases, including IPF, took place within a molecular approach. In this regard a biological marker can be defined as any expression of processes involving cells (proteins, metabolites, etc..) or of a gene that can transmit information on the state of health or disease of an individual and that, depending on the type of new information provided, can be used in a specific clinical setting (diagnosis, susceptibility, prognosis, etc.) [18].

Acquisitions of genomics may be of heterogeneous origin. The substrate most used, at least originally, was of course the lung tissue of IPF patients, obtained from lung biopsy, autopsy or explant [19].

In one study Selman et al. [20], employing microarrays techniques, showed a different gene expression profile in IPF compared to other chronic fibrosing lung diseases, in particular the hypersensitivity pneumonitis (HP). In a subsequent work [21] they reported a distinct biological and transcriptional structure in patients with "slow" and "progressive" forms of IPF.

Boon et al. [22], using a serial analysis of gene expression (SAGE), have confirmed a different gene expression in patients with IPF compared to healthy subjects or to patients with other respiratory conditions, and between "stable" and "accelerated" phenotypes in the same IPF. In addition, these AA [22] observed that some gene products 
related to progression of the disease were also found in biological fluids (blood and/or BAL).

Konishi et al. [23], still using microarray analysis, have emphasized a "molecular signature" distinguishable in acute exacerbations of IPF (AEIPF), and have observed that, in cases of AEIPF, the concomitant finding of an increased level of $\alpha$-defensins in the blood may envisage a clinical role for these peptides as biomarkers to be used for patients monitoring.

The regulation of gene expression is a particularly complex aspect, being able to modulation through not only a transcriptional and post-transcriptional control, but also an epigenetic one. Epigenetic is defined as the study of changes in transcriptional profile that do not involve changes in the DNA sequence, often in response to environmental stimuli, and heritable through cell generations [24]. The potential reversibility [25] of these events explains the growing interest in the possible therapeutic implications. Epigenomic analysis basically is based on evaluation of DNA methylation, histone modifications and the expression of microRNAs (miRNAs) [26]. Extensive evidence supports the importance of epigenetic mechanisms in the pathogenesis of IPF.

Sanders et al. [27] found no significant differences in global DNA methylation between normal and IPF lung, but for IPF they reported an altered activity of some enzymes methylating in specific anatomical regions (in particular, fibroblastic foci), which corresponded to an altered pattern of messenger RNA (mRNA), demonstrating the involvement of a number of disrupted genes.

Pandit et al. [28] have summarized the available data for miRNAs, short non-coding RNA molecules involved in post-transcriptional gene regulation and often associated with tissue dysfunction. In IPF a fundamental pathogenetic moment of the fibrosing process seems to be the epithelial-mesenchymal transition (EMT), a biological phenomenon that different miRNAs can promote (e.g. miR-2 [29], miR-155 [30]) or inhibit (e.g. Let-7d, miR-29) [31].

The importance of these observations is not limited to the understanding of the pathogenetic aspects only, since they may make possible, at least theoretically, to envisage a therapeutic strategy polarizing towards miRNAs with an antifibrosing action [32].

Epigenetic regulation, however, may act through multiple mechanisms and interferences. An in vitro study described the inhibition of histone deacetylation as a possible factor for a decrease in survival of lung fibroblasts from patients with IPF, resistant to apoptosis, through modifications of DNA methylation [25]. Dakhlallah et al. [33] identified in IPF a complex interactive circuit between an aberrant DNA methylation and the regulation of expression of the cluster MiR-17 92. In addition, a pharmacological modulation causing a re-expression of this gene cluster seemed to reduce the genes' fibrosing potential.

Feasibility of such sophisticated strategy is, of course, conditional upon the availability of lung tissue obtained by way of surgical biopsy, with the consequent limitations inherent to such an approach, in particular sampling variability (sampling bias) [34] and risk of AEIPF [35]. Other aspects should not be overlooked, such as the presence of comorbidities, in a disease that typically affects the elderly, and the mutability of interpretation of morphological patterns. This generates the need to make use of so-called "surrogate tissue", i.e. biological material obtained through partially invasive methods (blood, BAL) [19].

The search for markers in biological fluids substantially relies on serological analyses which led to the identification of various molecules. Following the current guidelines relating to the main pathogenetic biological elements involved, such molecules may be divided, according to their origin, into two categories: the compounds derived from type II pneumocytes and those derived from macrophages [36]. More recently, substances from the extracellular matrix have also been identified as potential biomarkers [37].

Surfactant proteins A and D (SP-A, SP-D) are lipoprotein complexes, synthesized by type II pneumocytes (AEC II) and by the Clara cells, mainly active in the reduction of the surface tension, but also functioning as a defense in the context of natural immunity. An increase in SP-A and SP-D [38] in serum from IPF patients, was linked to a presumed increase in the synthesis by hyperplastic AEC IIs or to transudation resulting from decomposition of the epithelium and basement membrane, and this increase was correlated with mortality. These studies seem therefore to suggest that SP-A and SP-D may be potential diagnostic and prognostic biomarkers [39].

Another molecule derived from respiratory epithelium (AEC II and bronchiolar cells) is the Krebs von den Lungen 6 Antigen (KL6) glycoprotein, a factor of fibroblast proliferation and survival [40,41], whose levels resulted high in both serum and BAL fluid [42] from patients with various interstitial lung diseases (ILD) of fibrosing character, both idiopathic (such as IPF and NSIP [43]) and associated with collagen-vascular disease [44]. Since serum levels $>1000 \mathrm{U} / \mathrm{ml}$ seem to be correlated with survival, measuring KL6 may have a prognostic significance in both the IIP and lung fibroses associated with collagen-vascular diseases [45].

The chemokine CCL18, synthesized by alveolar macrophages polarized towards the M2 phenotype [46], exerts a chemotactic action on fibroblasts, stimulating their collagen production [47]: CCL18 values $>150 \mathrm{ng} / \mathrm{ml}$ resulted predictive of mortality [48], which gives a useful prognostic value to this marker. 
The chemokine CCL2, produced by various cells including macrophages, while being correlated with the presence of pulmonary fibrosis in general and with the clinical course in IPF $[43,49]$, was increased also in other diseases so limiting its role as a biomarker.

The glycoprotein YKL-40, present in macrophages and epithelial cells, belongs to the family of chitinases and it regulates the growth and survival of mesenchymal cells [50], including fibroblasts. Elevated levels of YKL-40 were detected in both serum and BAL fluid of IPF patients $[50,51]$ and resulted correlated with survival, so that it might be a useful prognostic marker.

Calgranuline B (S100A9), expressed in macrophages and neutrophils, was detected at an abnormally high level in IPF compared to controls and other ILDs; it has therefore been proposed as a diagnostic biomarker [52].

The matrix metalloproteinases (MMPs) constitute a family of zinc-dependent endoproteases, involved in the degradation of the extracellular matrix, but also in the processing of many bioactive molecules. Rosas et al. [37] showed that a combined increase in serum MMP1 and MMP7 was discriminating between IPF and other ILDs or COPD, which suggested for these molecules a diagnostic role and, for MMP7 only, also a prognostic one, so that Richards et al. [53] have developed a mortalitypredictive multidimensional index involving integration of plasmatic MMP7, FVC and $\mathrm{DL}_{\mathrm{CO}}$.

In addition to molecular compounds, cellular elements have been proposed as biomarkers, in particular circulating fibrocytes, i.e. cells derived from bone marrow able to develop a mesenchymal differentiation (fibroblasts and myofibroblasts), and Moeller et al. [54] underlined that an increase in fibrocytes $>5 \%$ testifies a poor prognosis. A role as biomarkers has been suggested also for additional proteins (osteopontin, periostin) involved in the pathogenesis of IPF [17].

From the above findings in the literature one may easily gather that, regardless of etiology, various biological factors are involved and interact in the process of chronic remodeling and fibrosis of the lung: these factors can therefore potentially be used as biomarkers in both ILD [55] in general and particularly in IPF [17]. Concerning IPF, numerous studies have been conducted using biomolecular analyses to clarify various aspects of clinical significance. The objectives of such works were, however, directed to the study of pathogenetic mechanisms [56], in order to identify new therapeutic "targets", to diagnostic characterization of the specific phenotypes [22] (e.g. slow vs. fast progressors) of IPF, to the identification of the presence, extension [57] or prognosis [53] of the disease, or, finally, to describe a "pattern" of gene expression [20,23,58]. Biomolecular investigations on IPF were performed selectively on tissue samples, BAL, or blood, in a diagnostic context which had already been defined, and not with the aim of reaching an early diagnosis.

\section{Conclusions}

In conclusion, IPF is a progressive and fatal fibrosing lung disease, caused by a complex and only partially known interaction between exposure to pneumotoxic agents and predisposing conditions. The "multi-omic" approach may allow studying individual constitutional profiles resorting to a series of biomolecular disciplines, the so-called "omics", which provide various methods that are, at least in principle, complementary. Such an approach implies a shift from a "gene-centric" vision of IPF, in which a given phenotype is believed to derive from the response of a single gene to injury, to a global genome ("genome-wide") vision, which focuses on responses of the entire genomic complex [19], in line with the current trend to quantitatively analyze the interactions of all components of a biological system [59] in order to define the phenotype of various lung conditions ("systems biology").

In an age of "integrated" approach to respiratory diseases [60], made possible by implementation of biomolecular analytical technologies, and of "holistic" management of IPF [61], the use of biological markers may be extended from the search for molecules in blood to the identification of gene alterations [62] (single nuclear polymorphisms: SNP, gene mutations), as well as epigenetic ones [26] and changes in particular substances [63]. IPF, therefore, does not appear as a disease from an alteration of a single gene, although single mutations were found, such as those concerning the coding of the telomerase enzyme complex [64] or SNP, in particular in the gene encoding mucin 5B (MUC5B) [65], measurable on blood and BAL as well. These changes, however, may be regarded not as an expression of disease, but rather as an increased predisposing condition, while more significant clinical information could result from methods allowing accurate analyses of genetic and epigenetic expression [34,35] (e.g., miRNA, methylation). On the other hand proteomics research, being able to recognize specific protein clusters (MMP1 and 7, SPP1, YKL-40, etc.) [17], could complement genetic investigation and contribute to the building of a biological "profile" of the pathology: many of the current obstacles may be overcome through increased access to data from the Lung Tissue Research Consortium [66], founded by the National Health Institute with the aim of collecting biological and clinical material concerning respiratory diseases, particularly COPD and ILD.

Such refined investigations, which seem rather futuristic, are an essential base for research now, but they might become a routine in the near future, allowing a more precise classification of patients suffering from a 
disease that is at present so disappointing as to therapeutic response and prognostic expectation.

\section{Competing interests}

The authors declare that they have no competing interests.

\section{Author details}

${ }^{1}$ RespiratoryPhysiopathology Unit, ASL SA, Cava de' Tirreni, SA, Italy. ${ }^{2}$ Senior Consultant in Respiratory Medicine, Editor and Managing Director of

Multidisciplinary Respiratory Medicine, Rome, Italy.

Received: 8 July 2013 Accepted: 16 July 2013

Published: 9 August 2013

\section{References}

1. Raghu G: An Official ATS/ERS/JRS/ALAT statement: idiopathic pulmonary fibrosis: evidence-based guidelines for diagnosis and management. Am J Respir Crit Care Med 2011, 183:788-824.

2. Navaratnam V, Fleming KM, West J, Smith CJP, Jenkins RG, Fogarty A, Hubbard RB: The rising incidence of idiopathic pulmonary fibrosis in the UK. Thorax 2011, 66:462-467.

3. Raghu G, Weycker D, Edelsberg J, Bradford WZ, Oster G: Incidence and prevalence of Idiopathic Pulmonary Fibrosis. Am J Respir Crit Care Med 2006, 174:810-816.

4. Frankel SK, Schwarz MI: Update in idiopathic pulmonary fibrosis. Curr Opin Pulm Med 2009, 15:463-469.

5. Vancheri C, Failla M, Crimi N, Raghu G: Idiopathic pulmonary fibrosis: a disease with similarities and links to cancer biology. Eur Respir J 2010, 35:496-504

6. King TE Jr, Pardo A, Selman M: Idiopathic Pulmonary Fibrosis. Lancet 2011, 378:1949-1961.

7. Richeldi L: Assessing the treatment effect from multiple trials in idiopathic pulmonary fibrosis. Eur Respir Rev 2012, 21:147-151.

8. Cottin V: Changing the idiopathic pulmonary fibrosis treatment approach and improving patient outcome. Eur Respir Rev 2012, 21:161-167.

9. Noble PW, Albera C, Bradford WZ, Costabel U, Glassberg MK, Kardatzke D, King TE Jr, Lancaster L, Sahn SA, Szwarcberg J, Valeyre D, Du Bois R, CAPACITY Study Group: Pirfenidone in patients with idiopathic pulmonary fibrosis (CAPACITY): two randomised trials. Lancet 2011, 377:1760-1769.

10. Papiris SA, Kagouridis K, Kolilekas L, Triantafillidou C, Tsangaris I, Manali ED: Pirfenidone treatment in idiopathic pulmonary fibrosis: too much of a great expectation? Eur Respir J 2012, 40:794-795.

11. Albera C: Challenges in idiopathic pulmonary fibrosis trials: the point on end-points. Eur Respir Rev 2011, 20:195-200.

12. Martinez FJ, Safrin S, Weycker D, Starko KM, Bradford WZ, King TE Jr Flaherty KL, Schwartz DA, Noble PW, Raghu G, Brown KK, For the IPF Study Group: The clinical course of patients with Idiopathic Pulmonary Fibrosis. Ann Intern Med 2005, 142:963-967.

13. Kim DS, Collard HR, King TE Jr: Classification and natural history of the idiopathic interstitial pneumonias. Proc Am Thorac Soc 2006, 3:285-292.

14. Cottin V, Nunes H, Brillet PY, Delaval P, Devouassoux G, Tillie-Leblond I, Israel-Biet D, Court-Fortune I, Valeyre D, Cordier JF, The Grouped'Etude et de Recherchesur les Maladies "Orpheline" Pulmonaires (GERM"O"P): Combined pulmonary fibrosis and emphysema: a distinct underrecognised entity. Eur Respir J 2005, 26:586-593.

15. Nashimura K, Kitaichi M, Izumi T, Nagai S, Kanaoka M, Itoh H: Usual interstitial pneumonia: histologic correlation with high-resolution CT. Radiology 1992, 182:337-342.

16. Thomeer M, Grutters JC, Wuyts WA, Willems S, Demedts MG: Clinical use of biomarkers of survival in pulmonary fibrosis. Respir Res 2010, 11:89

17. Vij R, Noth I: Peripheral blood biomarkers in idiopathic pulmonary fibrosis. Transl Res 2012, 159:218-227.

18. Zhang $\mathrm{Y}$, Kaminski $\mathrm{N}$ : Biomarkers in idiopathic pulmonary fibrosis. Curr Opin Pulm Med 2012, 18:441-446.

19. Kaas DJ, Kaminski N: Evolving genomic approaches to idiopathic pulmonary fibrosis: moving beyond genes. Clin Trans/ Sci 2011, 4:372-379.

20. Selman M, Pardo A, Barrera L, Estrada A, Watson SR, Wilson K, Aziz N, Kaminski N, Zlotnik A: Gene expression profiles distinguish idiopathic pulmonary fibrosis from hypersensitivity pneumonitis. Am J Respir Crit Care Med 2006, 173:188-198.
21. Selman M, Carrillo G, Estrada A, Mejia M, Becerril C, Cisneros J, Gaxiola M, Pérez-Padilla R, Navarro C, Richards T, Dauber J, King TE Jr, Pardo A, Kaminski N: Accelerated variant of idiopathic pulmonary fibrosis: clinical behavior and gene expression pattern. PLoS One 2007, 5:482.

22. Boon K, Bailey NW, Yang J, Steel MP, Groshong S, Kervitsky D, Brown KK, Schwarz Ml, Schwartz DA: Molecular phenotypes distinguish patients with relatively stable from progressive Idiopathic Pulmonary Fibrosis (IPF). PLoS One 2009, 4:5134.

23. Konishi K, Gibson KF, Lindell KO, Richards TJ, Zhang Y, Dhir R, Bisceglie M, Gilbert S, Yousem SA, Song JW, Kim DS, Kaminski N: Gene expression profiles of acute exacerbation of Idiopathic Pulmonary Fibrosis. Am J Respir Crit Care Med 2009, 180:167-175.

24. Ecclestone A, De Witt N, Gunter C, Marte B, Nath D: Epigenetics. Nature 2007, 447:395.

25. Sanders YY, Hagood JS: The effects of histon deacetylase inhibitors on fibrotic lung fibroblasts survival and apoptosis. Am J Respir Crit Care Med 2010, 181:A2015

26. Yang IV, Schwartz DA: Epigenetic control of gene expression in the lung. Am J Respir Crit Care Med 2011, 183:1295-1301.

27. Sanders YY, Ambalavanan N, Halloran B, Zhang X, Liu H, Crossman DK, Bray M, Zhang K, Thannickal VJ, Hagood JS: Altered DNA methylation profile in Idiopathic Pulmonary Fibrosis. Am J Respir Crit Care Med 2012, 186:525-535.

28. Pandit KV, Milosevic J, Kaminski N: MicroRNAs in idiopathic pulmonary fibrosis. Transl Res 2011, 157:191-199.

29. Liu G, Friggeri A, Yang Y, Milosevic J, Ding Q, Thannickal VJ, Kaminski N, Abraham E: miR-21mediates fibrogenic activation of pulmonary fibroblasts and lung fibrosis. J Exp Med 2010, 207:1589-1597.

30. Pottier N, Maurin T, Chevalier B, Puisségur MP, Lebrigand K, Robbe-Sermesant K, Bertero T, Cardenas CLL, Courcot E, Rios G, Fourre S, Lo Guidice JM, Marcet B, Cardinaud B, Barbry P, Mari B: Identification of keratinocyte growth factor as a target of microRNA-155 in lung fibroblasts: implication in epithelial-mesenchymal interactions. PLoS One 2009, 4:e6718.

31. Pandit KV, Corcoran D, Yousef H, Yarlagadda M, Tzouvelekis A, Gibson KF, Konishi K, Yousem SA, Singh M, Handley D, Richards T, Selman M, Watkins SC Pardo A, Ben-Yehudah A, Bouros D, Eickelberg O, Ray P, Benos PV, Kaminski N: Inhibition and role of let-7d in Idiopathic Pulmonary Fibrosis. Am J Respir Crit Care Med 2010, 182:220-229.

32. Yang IV: Epigenomics of idiopathic pulmonary fibrosis. Epigenomics 2012 4:195-203.

33. Dakhlallah D, Batte K, Wang Y, Cantemir-Stone CZ, Yan P, Nuovo G, Mikhail A, Hitchcock CL, Wright VP, Nana-Sinkam SP, Piper MG, Marsh CB: Epigenetic regulation of miR-17 92 contributes to the pathogenesis of Pulmonary Fibrosis. Am J Respir Crit Care Med 2013, 187:397-405.

34. Flaherty KR, Travis WD, Colby TV, Toews GB, Kazeroony EA, Gross BH, Jain A, Strawdermann RL III, Flint A, Lynch JP III, Martinez FJ: Histopathologic variability in usual and nonspecific Interstitial Pneumonias. Am J Respir Crit Care Med 2001, 164:1722-1727.

35. Utz JP, Ryu JH, Douglas WW, Hartman TE, Tazelaar HD, Myers JL, Allen MS, Schroeder DR: High short-term mortality following lung biopsy for usual interstitial pneumonia. Eur Respir J 2001, 17:175-179.

36. Prasse A, Muller-Quernheim J: Non-invasive biomarkers in pulmonary fibrosis. Respirology 2009, 14:788-795.

37. Rosas IO, Richards TJ, Konishi K, Zhang Y, Gibson K, Lokshin AE, Lindell KO, Cisneros J, MacDonald SD, Pardo A, Sciurba F, Dauber J, Seman M, Gochuico BR, Kaminski N: MMP1 and MMP7 as potential peripheral blood biomarkers in Idiopathic Pulmonary Fibrosis. PLoS Med 2008, 5:93.

38. Greene KE, King TE Jr, Kuroki Y, Bucher-Bartelson B, Hunninghake GW, Newman LS, Nagae $H$, Mason RJ: Serum surfactants proteins-A and -D as biomarkers in idiopathic pulmonary fibrosis. Eur Respir J 2002, 19:439-446.

39. Kinder BW, Brown KK, Mc Cormack FX, Ix JH, Kervitski A, Schwarz MI, King TE Jr: Serum surfactant protein-A is a strong predictor of early mortality in Idiopathic Pulmonary Fibrosis. Chest 2009, 135:1557-1563.

40. Ohshimo S, Yokoyama A, Hattori N, Ishikawa N, Hirasawa Y, Kohno N: KL-6, a human MUC1 mucin, promotes proliferation and survival of lung fibroblasts. Biochem Biophys Res Commun 2005, 338:1845-1852.

41. Hirasawa Y, Kohno N, Yokohama A, Inoue Y, Abe M, Hiwada K: KL6, a human MUC1 mucin, is chemotactic for human fibroblasts. Am J Respir Cell Mol Biol 1997, 17:501-507.

42. Kobayas J, Kitamura S: KL-6: A serum marker for Interstitial Pneumonia. Chest 1995, 108:311-315 
43. Ohnishi H, Yokoama A, Kondo K, Hamada H, Abe M, Nishimura K, Hiwada K, Kohno N: Comparative study of KL-6, surfactant protein-A, surfactant protein-D, and monocyte chemoattractant protein-1 as serum markers for Interstitial Lung Diseases. Am J Respir Crit Care Med 2002, 165:378-381.

44. Kinoshita K, Hamano H, Harado H, Kinoshita T, Igishi T, Hagino H, Ogawa T: Role of KL-6 in evaluating the disease severity of rheumatoid lung disease: comparison with HRCT. Respir Med 2004, 98:1131-1137.

45. Satoh H, Kurishima K, Ishikawa H, Ohtsuka M: Increased levels of KL-6 and subsequent mortality in patients with interstitial lung diseases. $J$ Intern Med 2006, 260:429-434.

46. Mantovani A, Sica A, Sozzani S, Allavena P, Vecchi A, Locati M: The chemokine system in diverse forms of macrophage activation and polarization. Trends Immunol 2004, 25:677-686.

47. Prasse A, Pechkovsky DV, Toews GB, Jungraithmayr W, Kollert F, Goldman T, Vollmer E, Muller-Quernheim J, Zissel G: A vicious circle of alveolar macrophages and fibroblasts perpetuates Pulmonary Fibrosis via CCL8. Am J Respir Crit Care Med 2006, 173:781-792.

48. Prasse A, Probst C, Bargagli E, Zissel G, Toews GB, Flaherty KR, Olschevski M, Rottoli P, Müller-Quernheim J: Serum CC-chemokine ligand 18 concentration predicts outcome in Idiopathic Pulmonary Fibrosis. Am J Respir Crit Care Med 2009, 179:717-723.

49. Suga M, lyonaga K, Ichiyasu $H$, Saita N, Yamasaki H, Ando M: Clinical significance of MCP- 1 levels in BALF and serum in patients with interstitial lung diseases. Eur Respir J 1999, 14:376-382.

50. Furuhashi K, Suda T, Nakamura Y, Inui N, Hashimoto D, Miwa S, Hayakawa H, Kusagaya H, Nakano Y, Nakamura H, Chida K: Increased expression of YKL-40, a chitinase-like protein, in serum and lung of patients with idiopathic pulmonary fibrosis. Respir Med 2010, 104:1204-1210.

51. Korthagen NM, Van Moorsel CHM, Barlo NP, Ruven HJT, Kruit A, Heron M, van den Bosch JMM, Grutters JC: Serum and BALF YKL-40 levels are predictors of survival in idiopathic pulmonary fibrosis. Respir Med 2011, 105:106-113.

52. Hara A, Sakamoto N, Ishimatsu Y, Kakugawa T, Nakashima S, Hara S, Adachi M, Fujita H, Mukae $\mathrm{H}$, Kohno S: S100A9 in BALF is a candidate biomarker of pulmonary fibrosis. Respir Med 2012, 106:571-580.

53. Richards TJ, Kaminski N, Baribaud F, Flavin S, Brodmerkel C, Horowitz D, Li K, Choi J, Vuga LJ, Lindell KO, Klesen M, Zhang Y, Gibson KF: Peripheral Blood Proteins Predict Mortality in Idiopathic Pulmonary Fibrosis. Am J Respir Crit Care Med 2012, 185:67-76.

54. Moeller A, Gilpin SE, Ask K, Cox G, Cook D, Gauldie J, Margetts PJ, Farkas L, Dobranowski J, Boylan C, O'Byrne PM, Strieter RM, Kolb M: Circulating Fibrocyte Are an Indicator of Poor Prognosis in Idiopathic Pulmonary Fibrosis. Am J Respir Crit Care Med 2009, 179:588-594.

55. Nukiwa T: Interstitial Lung Disease. In The role of biomarkers in management of interstitial lung disease: implications of biomarkers derived from type II pneumocytes. 46th edition. Edited by Du Bois RM, Richeldi L. ERS Monograph; 2009:47-66.

56. Rottoli P, Bargagli E, Landi C, Magi B: Proteomic analysis in interstitial lung diseases: a review. Curr Opin Pulm Med 2009, 15:470-478.

57. Yang IV, Luna LG, Cotter J, Talbert J, Leach SM, Kidd R, Turner J, Kummer N, Kervitsky D, Brown KK, Boon K, Schwarz MI, Schwartz DA, Steele MP: The Peripheral Blood Transcriptome Identifies the Presence and Extent of Disease in Idiopathic Pulmonary Fibrosis. PLoS One 2012, 7:37708.

58. Rottoli P, Magi B, Perari MG, Liberatori S, Nikiforakis N, Bargagli E, Cianti R, Bini L, Pallini V: Cytokine profile and proteome analysis in bronchoalveolar lavage of patients with sarcoidosis, pulmonary fibrosis associated with systemic sclerosis and idiopathic pulmonary fibrosis. Proteomics 2005, 5:1423-1430.

59. Studer SM, Kaminski N: Towards systems biology of human Pulmonary Fibrosis. Proc Am Thorac Soc 2007, 4:85-91.

60. Center DM, Schwartz DA, Solway J, Gail D, Laposki AD, Lin QS, Gan W: Genomic medicine and lung diseases. Am J Respir Crit Care Med 2012, 186:280-285.

61. Lee JS, McLaughlin S, Collard HR: Comprehensive care of the patient with idiopathic pulmonary fibrosis. Curr Opin Pulm Med 2011, 17:348-354.

62. Yang IV, Burch LH, Steele MP, Savov JD, Hollingsworth JW, McElvania-Tekippe E, Berman KG, Speer MC, Sporn TA, Brown KK, Schwarz MI, Schwartz DA: Gene expression profiling of familial and sporadic Interstitial Pneumonia. Am J Respir Crit Care Med 2007, 175:45-54.

63. Danil ZD, Papageorgiou E, Koutsokera A, Kostikas K, Kiropoulos T, Papaioannou Al, Gourgoulianis Kl: Serum levels of oxidative stress as a marker of disease severity in idiopathic pulmonary fibrosis. Pulm Pharmacol Ther 2008, 21:26-31.

64. Cronkhite JT, Xing C, Raghu G, Chin KM, Torres F, Rosenblatt RL, Garcia CK: Telomere shortening in familial and sporadic Pulmonary Fibrosis. Am J Respir Crit Care Med 2008, 178:729-737.

65. Seibold MA, Wise AL, Speer MC, Steele MP, Brown KK, Loyd JE, Fingerlin TE, Zhang W, Gudmundsson G, Groshong SD, Evans CM, Garantziotis S, Adler KB, Dickey BF, Du Bois RM, Yang IV, Herron A, Kervitsky D, Talbert JL, Markin C, Park J, Crews AL, Slifer SH, Auerbach S, Roy MG, Lin J, Hennessy CM, Schwarz MI, Schwartz DA: A common MUC5B promoter polymorphism and Pulmonary Fibrosis. N Eng J Med 2011, 364:1503-1512.

66. Lung Genomics Research Consortium: www.lung-genomics.org

doi:10.1186/2049-6958-8-53

Cite this article as: Cicchitto and Sanguinetti: Idiopathic pulmonary fibrosis: the need for early diagnosis. Multidisciplinary Respiratory Medicine 2013 8:53.

\section{Submit your next manuscript to BioMed Central and take full advantage of:}

- Convenient online submission

- Thorough peer review

- No space constraints or color figure charges

- Immediate publication on acceptance

- Inclusion in PubMed, CAS, Scopus and Google Scholar

- Research which is freely available for redistribution 